Article

\title{
ATP- and Polyphosphate-Dependent Glucokinases from Aerobic Methanotrophs
}

\author{
Alexander S. Reshetnikov ${ }^{1}$, Natalia P. Solntseva ${ }^{2}$, Olga N. Rozova ${ }^{1}$, Ildar I. Mustakhimov ${ }^{1,2}$, \\ Yuri A. Trotsenko ${ }^{1,2}$ and Valentina N. Khmelenina ${ }^{1, *}$ \\ 1 Laboratory of Methylotrophy, G.K. Skryabin Institute of Biochemistry and Physiology of Microorganisms, \\ Russian Academy of Sciences, Federal Research Center "Pushchino Scientific Center for Biological Research \\ of the Russian Academy of Sciences", Pushchino 142290, Russia; reshetnikovas@rambler.ru (A.S.R.); \\ olgan.rozova@gmail.com (O.N.R.); mii80@rambler.ru (I.I.M.); trotsenko@ibpm.pushchino.ru (Y.A.T.) \\ 2 Department of Microbiology and Biotechnology, Pushchino State Institute of Natural Sciences, \\ Prospect Nauki 3, Pushchino 142290, Russia; natalia.solntseva.nn@gmail.com \\ * Correspondence: khmelenina@ibpm.pushchino.ru; Fax: +7-4959-563370
}

Received: 26 December 2018; Accepted: 12 February 2019; Published: 14 February 2019

\begin{abstract}
The genes encoding adenosine triphosphate (ATP)- and polyphosphate (polyP)-dependent glucokinases (Glk) were identified in the aerobic obligate methanotroph Methylomonas sp. 12. The recombinant proteins were obtained by the heterologous expression of the glk genes in Esherichia coli. ATP-Glk behaved as a multimeric protein consisting of di-, tri-, tetra-, penta- and hexamers with a subunit molecular mass of $35.5 \mathrm{kDa}$. ATP-Glk phosphorylated glucose and glucosamine using ATP $(100 \%$ activity), uridine triphosphate (UTP) $(85 \%)$ or guanosine triphosphate (GTP) $(71 \%)$ as a phosphoryl donor and exhibited the highest activity in the presence of $5 \mathrm{mM} \mathrm{Mg}^{2+}$ at $\mathrm{pH} 7.5$ and $65{ }^{\circ} \mathrm{C}$ but was fully inactivated after a short-term incubation at this temperature. According to a gel filtration in the presence of polyP, the polyP-dependent Glk was a dimeric protein $(2 \times 28 \mathrm{kDa})$. PolyP-Glk phosphorylated glucose, mannose, 2-deoxy-D-glucose, glucosamine and $\mathrm{N}$-acetylglucosamine using polyP as the phosphoryl donor but not using nucleoside triphosphates. The $K_{\mathrm{m}}$ values of ATP-Glk for glucose and ATP were about $78 \mu \mathrm{M}$, and the $K_{\mathrm{m}}$ values of polyP-Glk for glucose and polyP $\mathrm{P}_{(\mathrm{n}=45)}$ were 450 and $21 \mu \mathrm{M}$, respectively. The genomic analysis of methanotrophs showed that ATP-dependent glucokinase is present in all sequenced methanotrophs, with the exception of the genera Methylosinus and Methylocystis, whereas polyP-Glks were found in all species of the genus Methylomonas and in Methylomarinum vadi only. This work presents the first characterization of polyphosphate specific glucokinase in a methanotrophic bacterium.
\end{abstract}

Keywords: ATP-glucokinase; polyphosphate-glucokinase; methanotrophs; Methylomonas sp. 12

\section{Introduction}

Glucokinase (Glk, E.C. 2.7.1.63) catalyzes the phosphorylation of glucose into glucose 6-phosphate using nucleoside triphosphates and/or inorganic polyphosphate (polyP) as a phosphoryl donor. In prokaryotic and eukaryotic cells, Glk initiates the involvement of glucose in the central metabolic pathways. However, despite a wide distribution, the role of glucokinase in microorganisms is not quite clear. In Escherichia coli transporting glucose into cells via the phosphoenolpyruvate-dependent phosphotransferase system (PTS), Glk is not needed to support the growth on sugar as the deletion of the glk gene was not affected by the growth of the mutant strain [1,2]. A mutation analysis revealed that PTS is of major importance in permitting the rapid growth of $E$. coli on glucose It has been proposed that glucokinase in E. coli is necessary for the utilization of disaccharides consisting of glucose, such as lactose, maltose and trehalose, taken up by alternative mechanisms [1]. 
Aerobic bacteria utilizing methane as a carbon and energy source (methanotrophs) inhabit various natural systems where they mitigate this greenhouse gas emission [3]. Methanotrophs represent about 30 genera belonging to the phyla Proteobacteria and Verrucomicrobia, as well as to the candidate division NC10 [4-6]. Although all known methanotrophs are unable to grow on any sugars, most of them possess the Glk encoding genes [7]. ATP-dependent glucokinase (ATP-Glk) from the halotolerant methanotroph Methylomicrobium alcaliphilum 20Z has been biochemically characterized, and an essential role of the enzyme in the reutilization of free glucose derived from intracellular sucrose and glycogen has been revealed [7]. A preliminary genomic analysis showed that methanotrophs of the genus Methylomonas possess at least two glucokinase-like genes. However, the functioning of the glucokinase isozymes in methanotrophs has not been studied.

In the 1970s, the red pigmented obligate methanotroph was isolated from freshwater pool, and it has been previously described as "Methylomonas methanica" sp. 12 [8]. This bacterium has been intensively investigated as a potential producer of single cell proteins [9]. It was found that this methanotroph synthesizes inorganic polyphosphates, accumulating these compounds up to $6 \mathrm{mg} / \mathrm{g}$ of dry cells [10]. Here, we checked the phylogenetic position of this bacterium. In addition, two glucokinase encoding genes were identified and cloned, and recombinant enzymes were characterized. The distribution of polyphosphate dependent glucokinase in methanotrophs was analyzed.

\section{Materials and Methods}

\subsection{Bacteria and Growth Conditions}

The red pigmented obligate methanotroph "Methylomonas methanica" sp. 12 used in this study was previously isolated from a freshwater pool [8]. Now we sequenced the 16S rRNA encoding gene amplified by PCR with primers 27f/1492r [11] (Weisburg et al., 1991), as well as another taxonomically valuable gene $p m o A$ coding for a large subunit of the particulate methane monooxygenase using primers A189f/mb661r [12,13]. (Holmes et al., 1995; Costello \& Lidstrom, 1999) The 16S rDNA and pmoA sequences have been deposited in the GenBank under the accession numbers MK158248 and MK165450, respectively. The $16 \mathrm{~S}$ rDNA sequencing analysis showed $98 \%$ similarity with Methylomonas koyamae Fw12E-YT (AB538964) and only 94.4\% similarity with Methylomonas methanica $\mathrm{S}_{1}{ }^{\mathrm{T}}$ (AF304196) (Figure S1). A phylogenetic analysis showed that the $p m o A$ sequence from strain 12 branched within the Methylomonas group of pmoA sequences (Figure S2). This bacterium was designated as Methylomonas sp. 12. Methylomonas sp. 12 was grown at $30^{\circ} \mathrm{C}$ under a methane and air mixture (1:1) in a mineral medium $\mathrm{P}$ at $\mathrm{pH}$ 6.8 [8]. Escherichia coli Rosetta (DE3), obtained from Stratagene (La Jolla, CA, USA), was grown at $30{ }^{\circ} \mathrm{C}$ in a liquid or solid (1.5\% agar) LB medium [14] supplemented with $25 \mu \mathrm{g}$ kanamycin when necessary.

\subsection{Identification of Genes Coding for PolyP- and ATP-Dependent Glucokinases}

In the published genomes of Methylomonas species, two glucokinase-like genes coding for putative ATP-Glk and polyP-Glk have been found. Based on these sequences, two pairs of degenerate primers (GluK(F)A12/GluK(R)A12 and PolyGK-R/PolyGK-F2) were designed to amplify the internal fragments of these genes using the DNA of Methylomonas sp. 12 as a template (Table S1). The PCR fragments obtained were sequenced and the missing $5^{\prime}$ - and $3^{\prime}$-regions of each gene were identified by an inverse PCR. The genomic DNAs were broken up by endonucleases EcoRI and HindIII, and the DNA fragments were ligated to themselves by a T4 DNA ligase overnight at $16^{\circ} \mathrm{C}$. Following this, the DNA was precipitated from the ligase mixture by the addition of a 2.5 volume of ethanol and 0.1 volume of $3 \mathrm{M}$ sodium acetate, before being centrifuged during $30 \mathrm{~min}$ at $14,000 \times \mathrm{g}$. The sediments were washed sequentially by $80 \%$ and $96 \%$ ethanol and dissolved in a Tris-EDTA buffer (10 $\mathrm{mM}$ tris(hydroxymethyl)aminomethane- $\mathrm{HCl}, 1 \mathrm{mM}$ ethylenediaminetetraacetate, $\mathrm{pH}$ 8.0). The circular DNA molecules were used as a matrix in an inverse PCR. Based on the DNA fragments 
sequences, two pairs of the complementary primers GluKA12-F1/GluKA12-R1 and F2polGK/RpolGK were constructed for inverse PCRs to identify the $5^{\prime}$ - and $3^{\prime}$-regions of ATP- and polyP-dependent glucokinase encoding genes, respectively (Table S1). The obtained PCR products were sequenced and analyzed. The complete sequences of the $g l k$ and $p g l k$ genes coding for ATP-Glk and polyP-Glk were deposited into the Database NCBI (\#MH925106 and \#MH925105, respectively).

\subsection{Cloning of Glucokinases Encoding Genes}

The gene $g l k$ encoding putative ATP-Glk was amplified from the genomic DNA by the primers ATP-Glk-F and ATP-Glk-R (Table S1). The PCR product was treated by the endonucleases NdeI and SalI and ligated in the expression vector pET30(a)+ (Novagene), treated by the same restrictases. The entire polyP-Glk encoding gene ( $p g l k$ ) was amplified by using the primers Pol-Glk-F and Pol-Glk-R (Table S1), and the PCR product was treated by the endonucleases NdeI and XhoI. The resulting plasmids pET-polyP-glk and pET-ATP-glk were transferred to E. coli Rosetta (DE3), and the expression of the proteins was induced by $0.5 \mathrm{mM}$ isopropyl $\beta$-D-1-thiogalactopyranoside (Sigma-Aldrich, St. Louis, MO, USA) added in a logarithmic phase of growth $\left(\mathrm{A}_{600}=0.6-0.8\right)$. The cells were incubated during $18 \mathrm{~h}$ at $20^{\circ} \mathrm{C}$ and centrifuged for $20 \mathrm{~min}$ at $6000 \mathrm{~g}$.

\subsection{Purification of the Recombinant Proteins}

$0.5 \mathrm{~g}$ of transformed E. coli cells were re-suspended in $8 \mathrm{~mL}$ of $50 \mathrm{mM}$ Tris- $\mathrm{HCl}, \mathrm{pH} 8.0$, containing $500 \mathrm{mM} \mathrm{NaCl}$ and $5 \mathrm{mM}$ imidazol, and disrupted in a disintegrator Sonicator S-4000 (USA) for $10 \mathrm{~min}$ with $30 \mathrm{~s}$ cooling in ice after each $15 \mathrm{~s}$ of sonication. The homogenates were centrifuged for $30 \mathrm{~min}$ at $11,000 \times g$ and $4{ }^{\circ} \mathrm{C}$, and the supernatant was transferred into a column with $\mathrm{Ni}^{2+}$-NTA-agarose (Quiagen, Germany), equilibrated with the same buffer. The column was washed by three volumes of buffer B ( $50 \mathrm{mM}$ Tris-HCl, pH 8.0, containing $500 \mathrm{mM} \mathrm{NaCl}$ and $60 \mathrm{mM}$ imidasol). The protein was eluted by a buffer B containing $200 \mathrm{mM}$ imidazol. The proteins in the fractions were identified by sodium dodecyl sulfate-polyacrylamide gel electrophoresis (SDS-PAGE) [15]. The fractions containing proteins were dialyzed against a $100 \mathrm{mM}$ Tris- $\mathrm{HCl}$ buffer, $\mathrm{pH}$ 7.5, with $200 \mathrm{mM} \mathrm{NaCl}$.

\subsection{Determination of Molecular Masses of Glucokinases}

The native masses of the recombinant $\mathrm{N}$-terminal His-tagged glucokinases were determined by electrophoresis in a gradient of polyacrylamide gel (4-30\%) in a buffer solution ( $\mathrm{pH} 8.4)$ containing $190 \mathrm{mM}$ glycine and $90 \mathrm{mM}$ Tris-HCl [16]. After a preliminary electrophoresis during $15 \mathrm{~min}$ at $70 \mathrm{~V}$, the samples were re-dissolved in the same buffer supplemented by $10 \%$ glycerol and $0.5 \mu \mathrm{L} 1 \%$ bromphenol blue and electrophoresed again at $150 \mathrm{~V}$ during $15 \mathrm{~h}$. Thyroglobulin (669 $\mathrm{kDa})$, ferritin (440 kDa), amylase (232 kDa), alcohol dehydrogenase (140 kDa), and bovine serum albumin (BSA) $(67 \mathrm{kDa})$ (Sigma, USA) were used as protein markers.

The molecular masses of the glucokinases were also determined by a size exclusion chromatography using AKTAstart on a Tricorn Superdex 200 10/300 GL column (GE Healthcare) calibrated with the gel filtration standards purchased from Bio-Rad (Thyroglobulin $670 \mathrm{kDa} ; \gamma$-globulin, $158 \mathrm{kDa}$; ovalbumin, $44 \mathrm{kDa}$; myoglobin, $17 \mathrm{kDa}$; Vitamin B12, 1,3 kDa). As a running buffer $100 \mathrm{mM}$ Tris- $\mathrm{HCl}\left(\mathrm{pH} \mathrm{8.0)}, 100 \mathrm{mM} \mathrm{NaCl}\right.$, and $5 \mathrm{mM} \mathrm{MgCl}_{2}$ were used at a flow rate of $0.8 \mathrm{~mL} / \mathrm{min} .10 \mathrm{mM}$ polyP was added, if necessary, to the running buffer. Pure ATP-Glk-His 6 or polyP-Glk-His 6 (10 mg) was loaded onto the column. Fractions of $0.5 \mathrm{~mL}$ were collected. Aliquots from these fractions were tested for glucokinase activities and analysed by SDS-PAGE.

\subsection{Essay of Enzyme Activities}

To determine the activity of the ATP-Glk, the reduction of nicotinamide adenine dinucleotide phosphate $\left(\mathrm{NADP}^{+}\right.$) was registered in $1 \mathrm{~mL}$ of the reaction mixture containing $50 \mathrm{mM} \mathrm{K}$-phosphate buffer, pH 7.5, $5 \mathrm{mM}$ ATP, $5 \mathrm{mM} \mathrm{MgCl}_{2}, 0.5 \mathrm{mM} \mathrm{NADP}^{+}, 5 \mathrm{mM}$ glucose, and $5 \mathrm{U}$ glucose 6-phosphate dehydrogenase (GPD) at $340 \mathrm{~nm}$ on a spectrophotometer Shimadzu UV-1700 (Japan). The activity 
of the polyP-Glk was measured at $28^{\circ} \mathrm{C}$ in $1 \mathrm{~mL}$ of a reaction mixture containing $50 \mathrm{mM}$ Tris- $\mathrm{HCl}$ buffer, $\mathrm{pH} 8.5,5 \mathrm{mM}$ glucose, $2.5 \mathrm{mM} \mathrm{MgCl}_{2}, 0.5 \mathrm{mM} \mathrm{NADP}^{+}, 5 \mathrm{U}$ GPD, and $0.05 \mathrm{mM}$ polyP (Type 45, Sigma-Aldrich, USA).

The specificity of ATP-Glk to sugars (D-glucose, D-mannose, D-galactose, 2-deoxy-D-glucose, glucosamine, $\mathrm{N}$-acetylglucosamine, sucrose, maltose, trehalose, L-arabinose, D-xylose, ribose 5-phosphate, fructose 6-phosphate, glucose 6-phosphate or glucose 1-phosphate (Sigma-Aldrich, USA)) was determined in the reaction mixture containing a $50 \mathrm{mM}$ buffer: $5 \mathrm{mM}$ ATP, $25-50 \mathrm{mM} \mathrm{MgCl} 2,5$ $\mathrm{mM}$ phosphoenolpyruvate, $0.25 \mathrm{mM} \mathrm{NADH}, 5 \mathrm{U}$ pyruvate kinase, and $5 \mathrm{U}$ lactate dehydrogenase. The reaction was started by adding sugar $(5 \mathrm{mM})$. The sugar specificity of polyP-Glk was determined by testing a decrease of the polyP concentration [17]. The reaction mixture $(0.1 \mathrm{~mL})$ contained $50 \mathrm{mM}$ of Tris- $\mathrm{HCl}$ buffer, $\mathrm{pH}$ 8.5, $0.1 \mathrm{mM}$ polyP, $25 \mathrm{mM} \mathrm{MgCl}$, $15 \mathrm{mM}$ sugar (D-glucose, D-mannose, D-galactose, 2-deoxy-D-glucose, glucosamine, N-acetylglucosamine, sucrose, maltose, trehalose, L-sorbose, D-xylose, lactose) and $\sim 80 \mu \mathrm{g}$ polyP-Glk. After $10 \mathrm{~min}$ of incubation, a $10 \mu \mathrm{L}$ aliquot was placed into $1 \mathrm{~mL}$ of solution ( $6 \mathrm{mg}$ of toluidine blue in $1 \mathrm{~L}$ of $40 \mathrm{mM}$ acetic acid). The concentration of polyphosphate was calculated from the optical density ratio at 530/630 nm using the respective concentration of polyP as a standard. The absorption spectra were registered in a spectrophotometer Shimadzu UV-160 (Japan).

\subsection{Biochemical Characterization of Glucokinases}

To study the $\mathrm{pH}$ dependence of the enzyme activities, the following buffers were used (50 $\mathrm{mM})$ : MES-NaOH (pH 5.5-6.0), K-phosphate (pH 6.0-8.0), Tris-HCl (pH 7.6-8.9), CHES-NaOH (9.0-10.0); and glycine- $\mathrm{NaOH}(9.0-10.5)$. To check the temperature optima, the reactions were performed in the temperature range of 10 to $70^{\circ} \mathrm{C}$. To study the thermostability, the enzyme aliquots were heated for 5-180 $\mathrm{min}$ at $30-65{ }^{\circ} \mathrm{C}$, and the residual activities were measured in the standard conditions. The effect of metals was tested using the aqueous solutions of $\mathrm{ZnCl}_{2}, \mathrm{CaCl}_{2}, \mathrm{BaCl}_{2}, \mathrm{MnCl}_{2}, \mathrm{CoCl}_{2}$, $\mathrm{CdCl}_{2}, \mathrm{SrCl}_{2}, \mathrm{CuCl}_{2}, \mathrm{NiCl}_{2}, \mathrm{CsCl}, \mathrm{RbCl}$ or $\mathrm{LiCl}$ (at final concentrations of 5 or $1 \mathrm{mM}$ ), and of $\mathrm{NaCl}$ or $\mathrm{KCl}$ at different concentrations. The specificity to the phosphoryl donor was investigated in the standard reaction mixture where ATP was replaced by cytosine triphosphate (CTP), GTP, UDP or adenosine diphosphate (ADP) $(5 \mathrm{mM})$, by inorganic pyrophosphate (PPi) or tripolyphosphate (PPPi) $(2-3 \mathrm{mM})$ as well as by polyP $45(0.1 \mathrm{mM}) . K_{m}$ and $V_{\max }$ were calculated from the enzyme activity measured at various concentrations of one substrate and the saturated concentration of another. The ranges of the glucose concentration were $0.161-20 \mathrm{mM}$; for ATP, they were $0.161-10 \mathrm{mM}$, and they were $0.4-6.25 \mu \mathrm{M}$ for polyP.

\subsection{Analysis of Nucleotide and Amino Acid Sequences}

The comparative analyses of protein sequences were performed by using PSI-BLAST (http: //www.ncbi.nlm.nih.gov). The analysis of nucleotide sequences, determination of restriction sites and open reading frames were performed by using program VectorNTI v.9.0. The alignment of amino acid sequences was performed via ClustalX (v1.62b) [18]. The phylogenetic analysis was conducted by using MEGA6 (model Neighbor-Joining) [19].

\section{Results}

\subsection{Identification of Glucokinase Encoding Genes in Methylomonas sp. 12 and Purification of Glucokinases}

The crude sonic extracts of Methylomonas sp. 12 catalyzed a glucose phosphorylation into glucose 6-phosphate in the presence of either ATP or polyphosphate with an activity of 0.054 and $0.0058 \mathrm{U} / \mathrm{mg}$ of protein, respectively. By using inverse PCR, two genes encoding glucokinase isozymes were identified in the DNA of Methylomonas sp. 12. One gene of 990 b.p. encoded putative Glk sharing a 67\% identity to the recently characterized ATP-Glk from the halotolerant methanotroph $\mathrm{Mm}$. alcaliphilum 
20Z [7], while another gene of 795 b.p. encoded an enzyme mostly similar (40\% identity) to polyP-Glk from Propionibacterium freudenreichii [20].

The SDS-PAGE of the proteins obtained by the heterologous expression of the $g l k$ and $p g l k$ genes in Esherichia coli showed one protein band of about $35 \mathrm{kDa}$ for ATP-Glk and $30 \mathrm{kDa}$ for polyP-Glk (Figure 1). These values were in good agreement with the theoretically calculated subunit sizes of $35.5 \mathrm{kDa}$ and $28.1 \mathrm{kDa}$.

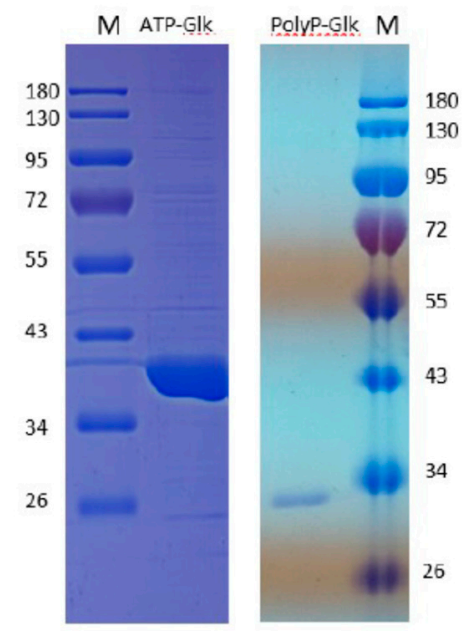

Figure 1. $12 \%$ sodium dodecyl sulfate-polyacrylamide gel electrophoresis of $100 \mu \mathrm{g}$ recombinant ATP-dependent glucokinase and $20 \mu \mathrm{g}$ polyP-dependent glucokinase from Methylomonas sp. 12. $\mathrm{M}$-markers of molecular masses, $\mathrm{kDa}$.

The gradient electrophoresis of ATP-Glk-His ${ }_{6}$ in non-denaturation conditions revealed several protein bands of $\sim 71 \mathrm{kDa}$ (dimer), $106.5 \mathrm{kDa}$ (trimer), $142 \mathrm{kDa}$ (tetramer), $177.5 \mathrm{kDa}$ (pentamer) and $213 \mathrm{kDa}$ (hexamer). The structure of the enzyme was differed from that of Mm. alcaliphilum ATP-Glk which was a homodimeric enzyme [7]. According to the gel-filtration, the $M r$ of polyP-Glk was $\sim 28 \mathrm{kDa}$, which doubled to $\sim 60 \mathrm{kDa}$ when polyP was added to the enzyme. The dimerization of the enzyme in the presence of polyphosphate has been previously reported for polyP/ATP-dependent Glk from Corynebacterium glutamicum [21]. Most the polyP-Glks investigated so far were either monomeric with a molecular weight of $30-50 \mathrm{kDa}$, or homodimeric [22,23].

\subsection{Biochemical Properties of ATP-Glk}

ATP-Glk from Methylomonas sp. 12 catalyzed the phosphorylation of glucose in the presence of ATP (100\% of activity), UTP ( $85 \%$ ) and GTP $(71 \%)$, but CTP, ADP, PPi or polyP did not serve as donors of the phosphoryl groups. ATP-Glk was active in a wide $\mathrm{pH}$ range (from $\mathrm{pHs} 5.0$ to 9.5) with a maximum activity at $\mathrm{pH} 7.5$, but its activity was sharply lost at $\mathrm{pH}>9.0$ (Figure $2 \mathrm{~A}$ ). It displayed the highest activity at $70{ }^{\circ} \mathrm{C}$ (Figure $2 \mathrm{~B}$ ) but fully inactivated after a 5 min incubation at $65^{\circ} \mathrm{C}$.

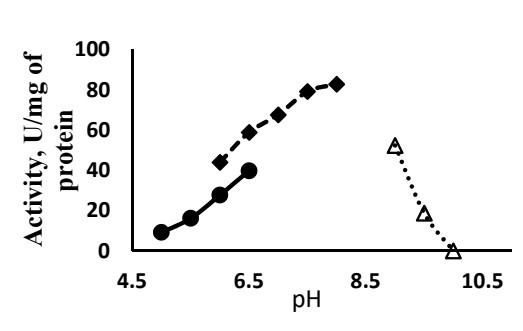

(A)

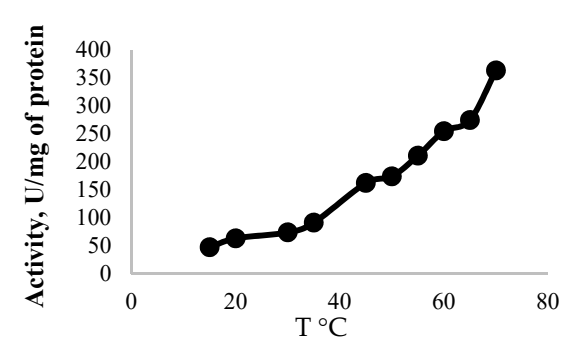

(B)

Figure 2. Effect of the $\mathrm{pH}(\mathbf{A})$ and the temperature (B) on the activity of ATP-dependent glucokinase from Methylomonas sp. 12. 
ATP-Glk phosphorylated glucose and glucosamine but other sugars (see Material and Methods section) did not serve as acceptors of the phosphoryl groups. The enzyme activity was dependent on divalent metals: $\mathrm{Mg}^{2+}\left(100 \%\right.$ activity), $\mathrm{Mn}^{2+}(60 \%), \mathrm{Sr}^{2+}(30 \%), \mathrm{Co}^{2+}(18 \%), \mathrm{Ni}^{2+}(13 \%), \mathrm{Cd}^{2+}(11 \%)$, $\mathrm{Cu}^{2+}(3 \%)$. The highest activity was observed in the presence of $5 \mathrm{mM}$ of $\mathrm{MgCl}_{2}$. It also displayed activity if $\mathrm{Mg}^{2+}$ was replaced by monovalent metal ions at a concentration of $5 \mathrm{mM}: \mathrm{Li}^{+}(72 \%$ of activity with $\left.\mathrm{Mg}^{2+}\right), \mathrm{Rb}^{+}(73 \%), \mathrm{Cs}^{+}(52 \%)$, or $\mathrm{Na}_{2} \mathrm{MoO}_{4}(66 \%)$. When $\mathrm{NaCl}(0.5 \mathrm{M})$ was added into the reaction mixture, the enzyme lost $50 \%$ of its activity. ADP inhibited the enzyme activity, while another reaction product, glucose 6-phosphate, had no appreciable effect on its activity (Table 1). A similar effect of ADP was reported for ATP-Glk from Mm. alcaliphilum 20Z [7].

Table 1. Effect of different metabolites on the activities of ATP- and polyP-dependent glucokinases from Methylomonas sp. 12.

\begin{tabular}{|c|c|c|}
\hline Effector, mM & ATP-Glk * & PolyP-Glk ** \\
\hline Control & $100 *$ & $100 * *$ \\
\hline Phosphoenolpyruvate, 5 & 99.8 & 111.3 \\
\hline Pyruvate, 5 & 114.9 & 103.3 \\
\hline Fructose-1-phosphate, 5 & 78.8 & 101.4 \\
\hline Fructose-6-phosphate, 5 & 115.8 & 103.0 \\
\hline Fructose-1,6- phosphate, 5 & 101.6 & 101.4 \\
\hline Glucose-1- phosphate, 5 & 101.7 & 107.2 \\
\hline Ribose-5-phosphate & nt & 117.8 \\
\hline Adenosine triphosphate & 100 & 155.0 \\
\hline Adenosine diphosphate, 5 & 48.9 & 93.0 \\
\hline Adenosine monophosphate, 5 & 110.3 & 84.1 \\
\hline $\mathrm{KH}_{2} \mathrm{PO}_{4}, 3$ & 86.1 & nt \\
\hline Glycerate, 1 & 109.0 & nt \\
\hline Oxaloacetate, 1 & 108.8 & 105.3 \\
\hline$\alpha$-Ketoglutarate, 1 & 108.8 & 99.7 \\
\hline Malate, 1 & 111.9 & 101.6 \\
\hline Citrate, 1 & 76.6 & 106.7 \\
\hline Isocitrate, 1 & 115.7 & nt \\
\hline Succinate, 1 & 114.9 & nt \\
\hline Polyphosphate, 0.075 & 117.3 & 100 \\
\hline Inorganic pyrophosphate, 2 & 82.3 & 104.0 \\
\hline Glyceraldehyde-3-phosphate & nt & 111.6 \\
\hline
\end{tabular}

* the reaction with ATP and glucose as substrates; ${ }^{* *}$ the reaction with polyphosphate $(\mathrm{n}=45)$ and glucose as substrates; nt not tested. The average values of three repeats of each reaction are presented.

The substrate saturation curves of ATP-Glk obeyed the Michaelis-Menten equation. At $30{ }^{\circ} \mathrm{C}$ and $\mathrm{pH} 7.5$, the $K_{\mathrm{m}}$ values for the glucose and ATP were: $0.08 \pm 0.007$ and $0.078 \pm 0.0056 \mathrm{mM}$, respectively (Table 2). The $V_{\max }$ values with glucose, glucosamine and ATP were $92.5 \pm 1.8,94.4 \pm 1.9$ and $106.4 \pm 2.4 \mathrm{U} / \mathrm{mg}$ of protein, respectively. Glk showed a high catalytic efficiency, since the ratio of $k_{\text {cat }} / K_{\mathrm{m}}$ was 82.09 for glucose and 96.85 for ATP.

\subsection{Biochemical Properties of PolyP-Glk}

PolyP-Glk from Methylomonas sp. 12 was active at a $\mathrm{pH}$ range of 5.5-10.5, displaying a maximum activity at $\mathrm{pH} 8.5$ and temperature $65^{\circ} \mathrm{C}$ (Figure 3A,B). The alkaline $\mathrm{pH}$ optima have been found for polyP-Glk from C. glutamicum and Thermobifida fusca [21,24]. PolyP-Glk from Methylomonas sp. 12 was completely inactivated after heating for $5 \mathrm{~min}$ at $60-65{ }^{\circ} \mathrm{C}$ or after $30 \mathrm{~min}$ at $55{ }^{\circ} \mathrm{C}$. After two hours of incubation at $35{ }^{\circ} \mathrm{C}$ and $40{ }^{\circ} \mathrm{C}$, the residual activities were $36 \%$ and $5 \%$ of the initial activities. After a $2 \mathrm{~h}$ exposure at $28^{\circ} \mathrm{C}$, the enzyme retained more than $70 \%$ of its activity. High temperature optima were found for polyP-Glk from Thermobifida fusca $\left(55^{\circ} \mathrm{C}\right)$ and polyphosphate/ATP-glucomannokinase from Arthrobacter sp. KM $\left(50^{\circ} \mathrm{C}\right)[25]$. 
Table 2. Kinetic parameters of ATP- and polyphosphate-dependent glucokinases from Methylomonas sp. 12.

\begin{tabular}{|c|c|c|c|}
\hline \multirow{2}{*}{ Parameter } & \multirow{2}{*}{ Substrate } & \multicolumn{2}{|c|}{ Values } \\
\hline & & ATP-Glk & PolyP-Glk \\
\hline \multirow{4}{*}{$V_{\max }(\mathrm{U} / \mathrm{mg})$} & Glucose & $92.5 \pm 1.8$ & $7.04 \pm 0.39$ \\
\hline & Glucosamine & 94.4 & \\
\hline & ATP & $106.4 \pm 2.4$ & - \\
\hline & $\operatorname{PolyP}_{(\mathrm{n}=45)}$ & - & $7.28 \pm 0.45$ \\
\hline \multirow{3}{*}{$K_{m a p p}(\mathrm{mM})$} & Glucose & $0.08 \pm 0.007$ & $0.45 \pm 0.12$ \\
\hline & ATP & $0.078 \pm 0.0056$ & - \\
\hline & $\operatorname{PolyP}_{(\mathrm{n}=45)}$ & - & $0.021 \pm 0.0039$ \\
\hline \multirow{3}{*}{$k_{\text {cat }}$ substrate $(1 / \mathrm{min})$} & Glucose & 6.57 & 0.395 \\
\hline & ATP & 7.55 & - \\
\hline & PolyP $_{45}$ & - & 0.409 \\
\hline \multirow{3}{*}{$k_{\text {cat }} / K_{m}(1 / \mathrm{min} \mathrm{mM})$} & Glucose & 82.09 & 0.87 \\
\hline & ATP & 96.85 & - \\
\hline & $\operatorname{PolyP}_{(n=45)}$ & - & 19.476 \\
\hline
\end{tabular}

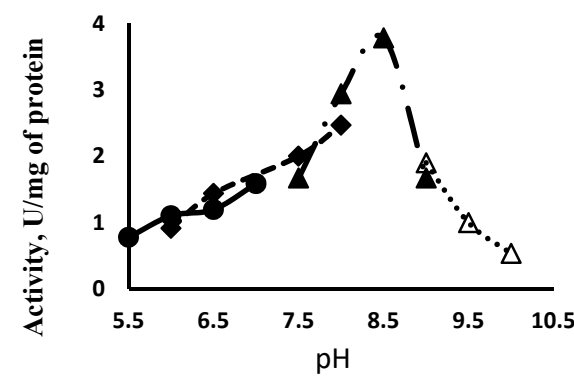

(A)

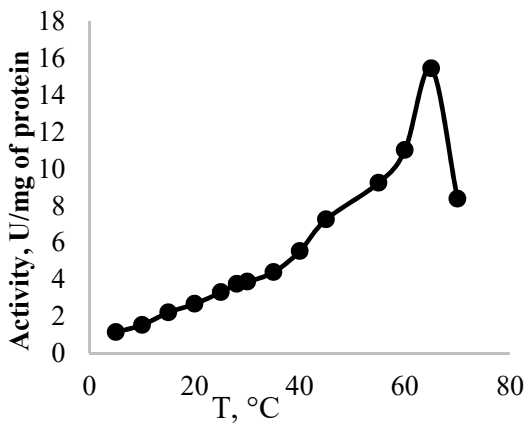

(B)

Figure 3. Effect of the temperature (A) and the $\mathrm{pH}(\mathbf{B})$ on the activity of polyphosphate-dependent glucokinase from Methylomonas sp. 12.

PolyP-Glk from Methylomonas sp. 12 did not use ATP, GTP, CTP, UTP, ADP, PPi or PPPi as phosphoryl donors. So far, only three glucokinases have been described as having a strong specificity to polyphosphates: the enzyme from Anabaena sp. PCC 7120 (All1371), from Microlunatus phosphovorus [26,27], and that from mammalian hepatocytes [28]. Most other characterized polyP-Glks also used ATP, and/or other nucleoside triphosphates or ADP.

Besides glucose, polyP-Glk from Methylomonas sp. 12 phosphorylated mannose, 2-deoxy-D-glucose, glucosamine and $\mathrm{N}$-acetylglucosamine, but did not use fructose, galactose, arabinose, L-sorbose, xylose, trehalose, ribose, sucrose lactose, glucose 1-phosphate, glucose 6-phosphate, fructose 1-phosphate or fructose 6-phosphate as an acceptor of the phosphoryl group. Its activity was dependent on divalent metal ions: $\mathrm{Mg}^{2+}\left(100 \%\right.$ activity), $\mathrm{Mn}^{2+}(80 \%), \mathrm{Co}^{2+}(79 \%)$, $\mathrm{Cd}^{2+}(44 \%), \mathrm{Ca}^{2+}(13 \%)$ or $\mathrm{Ni}^{2+}(10 \%)$. It had a negligible activity if $\mathrm{Mg}^{2+}$ was replaced by $1 \mathrm{mM}$ of monovalent metals: $\mathrm{Li}^{+}$or $\mathrm{Rb}^{+}(3.5 \%)$, or $\mathrm{Cs}^{+}(2 \%)$. The cations $\mathrm{Co}^{2+}, \mathrm{Ba}^{2+}, \mathrm{Ca}^{2+}, \mathrm{Zn}^{2+}$ and $\mathrm{Cu}^{2+}$ did not significantly influence the enzyme activity in the presence of $\mathrm{Mg}^{2+}$. The highest activity was observed in the presence of $2.5 \mathrm{mM}$ of $\mathrm{MgCl}_{2}$ and $100 \mathrm{mM}$ of $\mathrm{NaCl}$. At $28^{\circ} \mathrm{C}$ and pH 8.5, the $K_{\mathrm{m}}$ values were: $0.45 \pm 0.12 \mathrm{mM}$ for glucose, and $0.021 \pm 0.0039 \mathrm{mM}$ for polyP (Table 2). The $V_{\max }$ were $7.04 \pm 0.39 \mathrm{U} / \mathrm{mg}$ of protein for glucose, and $7.28 \pm 0.45 \mathrm{U} / \mathrm{mg}$ of protein for polyP.

The activity of polyP-Glk was increased in the presence of $10 \mathrm{mM}$ of ATP (Figure S3). An activating effect of ATP on polyP-dependent glucokinases has not been described previously. In contrast, competitive inhibition by high concentrations of ATP has been revealed for the Mycobacterium tuberculosis polyP-Glk that formed an enzyme-ATP-ATP complex [29]. Glucose 6-phosphate had no apparent effect on the polyP-Glk activity. 


\subsection{Distribution of Glucokinases in Methanotrophs}

ATP-Glk and polyP-Glk from Methylomonas sp. 12 shared a negligible similarity (only a 15\% identity of amino acid sequences, IAA). The genes for putative ATP-Glk were found in genomes of all methanotrophs known to date, with exception of alphaproteobacterial methanotrophs of the Methylosinus and Methylocystis genera from the Methylocystaceae family (Figure 4). The methanotrophic glk genes are well conserved (48-70\% of IAA). ATP-Glks of Methylomonas sp. 12 were mostly similar to those from Methylomonas methanica $\mathrm{S}_{1}$ and Methylomonas lenta (74-79\% IAA) but had only 32-33\% IAA with glucokinases from E. coli, Zymomonas mobilis (group A of glucokinases) and from Bacillus subtilis (group B of glucokinases) [30,31].

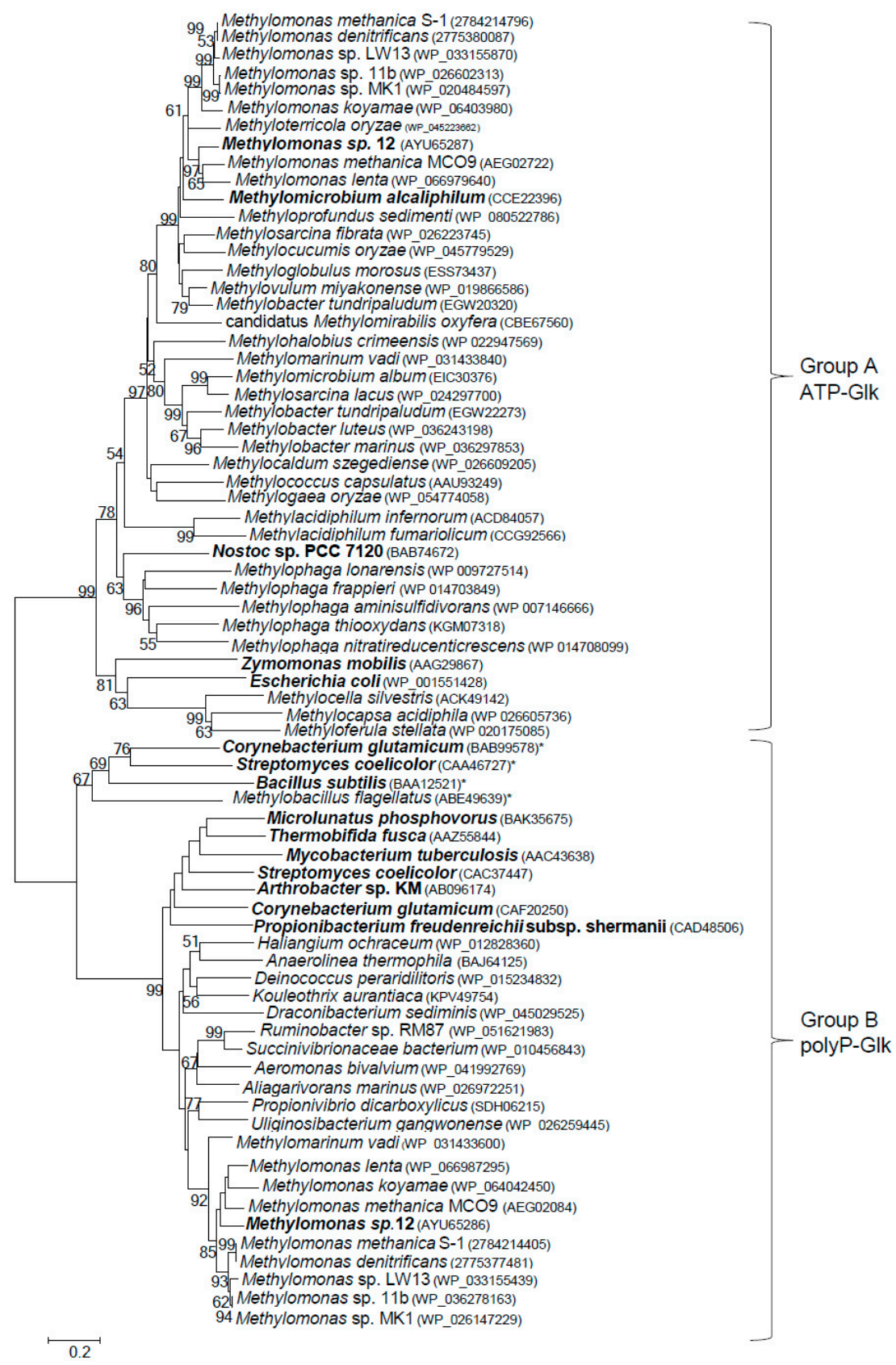

Figure 4. Phylogenetic tree constructed from the amino acid sequences of various putative and characterized bacterial ATP- and polyP-dependent glucokinases. The characterized enzymes are in bold and the amino acid accession numbers are in brackets. ATP-dependent glucokinases in the Group $\mathrm{B}$ are marked by asterisks. The scale bar corresponds to the number of substitutions per site. 
The $p g l k$-like genes were found in all methanotrophs of the Methylomonas genus sequenced to date and also in Methylomarinum vadi, another gammaproteobacterial methanotroph. In the NCBI database, these genes were usually annotated as the ROK (Repressor, ORF, Kinase) proteins. However, the methanotrophic polyP-Glks do not possess the conserved sequence CXCGXXGCXE containing three cysteine residues occurring in the ROK family proteins which were found for the first time in the Bacillus subtilis ATP-Glk (GenBank NP_390365) [22].

\section{Discussion}

In this paper we have demonstrated for the first time that the obligate methanotroph Methylomonas sp. 12 expresses two functional (ATP- and polyP-dependent) glucokinases. ATP-dependent glucokinase is present in all sequenced methanotrophs, with the exception of the genera Methylosinus and Methylocystis, whereas polyP-Glks have been found only in methanotrophs of the genus Methylomonas, as well as in Methylomarinum vadi. There is an appreciable homology between methanotrophic ATP-Glks clustering together on the phylogenetic tree. The polyP-Glks of methanotrophs also comprise a coherent group of proteins, whereas ATP- and polyP-dependent glucokinases are highly divergent enzymes (Figure 4).

There is a rather high sequence identity (67\%) between ATP-Glks from Methylomonas sp. 12 and that from another gammaproteobacterial methanotroph, Mm. alcaliphilum 20Z [7]. These enzymes also display similar biochemical properties, phosphorylating glucose and glucosamine and showing close temperature optima $\left(60-65^{\circ} \mathrm{C}\right)$, as well as instability at these temperatures. ADP inhibited the activities of both methanotrophic ATP-dependent glucokinases. The high affinity to glucose suggests that the enzyme from Methylomonas sp. 12, similar to the Mm. alcaliphilum ATP-Glk, can be involved in the scavenging of free glucose formed during the cleavage of intracellular glycogen [7]. Glycogen-like inclusions have been earlier demonstrated in the cells of Methylomonas sp. 12 [8]. Furthermore, it has been proven that exogenous glucose can enter the cells of Methylomonas sp. 12 and be an additional carbon source, since about $17 \%$ of cellular carbon originated from sugar during the culture growth under methane in the presence of $3 \mathrm{mM}$ of radiolabeled glucose [32].

In contrast to ATP-Glk, polyP-Glk from Methylomonas sp. 12 demonstrated a strong specificity to polyP and a high $\mathrm{Km}$ value for glucose $(450 \mu \mathrm{M})$. It also uses a wider range of acceptors of phosphoryl groups and, therefore, different physiological functions of the two enzymes in this bacterium can be suggested. In Anabaena sp. PCC 7120, the switching of the ATP-dependent glucokinase to the polyP-dependent enzyme in response to nitrogen starvation has been revealed. In mature heterocysts of the cyanobacterium, polyP-Glk can be involved in saving ATP for nitrogen fixation [27]. We hypothesize that two Glks in Methylomonas and M. vadi are also involved in overcoming environmental stresses. Importantly, M. vadi was isolated from a shallow submarine hydrothermal system, where it can be exposed to stressful conditions. In addition, Methylomonas and Methylomarinum are rather related genera in the context of the phylogeny of the PmoA-encoding genes (Figure S2) and of the similarity of other biochemical features distinguishing them from other gammaproteobacterial methanotrophs. For example, they have similar isoprenoid quinone compositions and possess phosphoenolpyruvate carboxylase, which is absent in other gammaproteobacterial methanotrophs [33,34]. The specificity of polyP-Glk towards glucose, mannose, 2-deoxy-D-glucose, glucosamine and $\mathrm{N}$-acetylglucosamine (presumably formed during cell lysis in microbial communities or autolysis) may imply the participation of the enzyme in the survival of Methylomonas sp. 12 under methane limitation conditions.

Interestingly, among methanotrophs, only members of the family Methylocystaceae (the genera Methylosinus and Methylocystis) lack the genes for Glk. However, a Blast analysis revealed that the alphaproteobacterial methanotrophs of both Methylocystaceae and Beyerinkiaceae families possess homologues of the genes encoding the putative phosphoenolpyruvate phosphotransferase system, thereby implying that all methanotrophs are potentially able to use glucose as an additional carbon source. Altogether, our observations promote our understanding of the metabolic flexibility of obligate 
methanotrophs, including their high survival potential in nature, but again raise a long-standing question about the biochemical basis of their obligate dependence on C1-compounds.

Supplementary Materials: The following are available online at http:/ / www.mdpi.com/2076-2607/7/2/52/s1. Figure S1: The phylogenetic position of Methylomonas strain 12 among methanotrophs of the Gammaproteobacteria class and the genus Methylomonas. The methanotroph of the class Alphaproteobacteria, Methylocystis parous, was used as an outgroup. Accession numbers are given in parentheses. Bar, 0.02 substitutions per nucleotide position; Figure S2: Phylogenetic analysis of the derived PmoA sequence from Methylomonas sp. 12. Bar, 0.02 substitutions per nucleotide position. The methanotroph of the class Alphaproteobacteria, Methylocystis parvus, was used as an outgroup; Figure S3: Effect of ATP on activity of polyP-Glk from Methylomonas sp. 12. PolyP Glk does not use ATP as a substrate in the absence of polyP.

Author Contributions: Conceptualization, V.N.K.; Formal analysis, O.N.R.; Investigation, A.S.R.; Methodology, N.P.S.; Project administration, Y.A.T.; Resources, I.I.M.

Acknowledgments: This work was supported by the Russian Scientific Foundation \#18-14-00326. The authors are grateful to all members of the Organization for Methanotroph Genome Analysis for collaboration (OMeGA), the U.S. Department of Energy Joint Genome Institute and Genoscope for the access to methanotrophic genomes for comparative analyses.

Conflicts of Interest: The authors declare no conflict of interest.

\section{References}

1. Curtis, S.J.; Epstein, W. Phosphorylation of D-glucose in Escherichia coli mutants defective in glucosephosphotransferase, mannosephosphotransferase, and glucokinase. J. Bacteriol. 1975, 122, 1189-1199. [PubMed]

2. Postma, P.W.; Lengeler, J.W.; Jacobson, G.R. Phosphoenolpyruvate:carbohydrate phosphotransferase systems of bacteria. Microbiol. Rev. 1993, 57, 543-594.

3. Hanson, R.S.; Hanson, T.E. Methanotrophic Bacteria. Microbiol. Rev. 1996, 60, 439-471. [PubMed]

4. McDonald, I.R.; Bodrossy, L.; Chen, Y.; Murrell, J.C. Molecular ecology techniques for the study of aerobic methanotrophs. Appl. Environ. Microbiol. 2008, 74, 1305-1315. [CrossRef] [PubMed]

5. Op den Camp, H.J.M.; Islam, T.; Stott, M.B.; Harhangi, H.R.; Hynes, A.; Schouten, S.; Jetten, M.S.M.; Birkeland, N.-K.; Pol, A.; Dunfield, P.F. Environmental, genomic and taxonomic perspectives on methanotrophic Verrucomicrobia. Environ. Microbiol. 2009, 1, 293-306. [CrossRef]

6. Ettwig, K.F.; Butler, M.K.; Le Paslier, D.; Pelletier, E.; Mangenot, S.; Kuypers, M.M.; Schreiber, F.; Dutilh, B.E.; Zedelius, J.; de Beer, D.; et al. Nitrite-driven anaerobic methane oxidation by oxygenic bacteria. Nature 2010, 464, 543-548. [CrossRef] [PubMed]

7. Mustakhimov, I.I.; Rozova, O.N.; Solntseva, N.P.; Khmelenina, V.N.; Reshetnikov, A.S.; Trotsenko, Y.A. The properties and potential metabolic role of glucokinase in halotolerant obligate methanotroph Methylomicrobium alcaliphilum 20Z. Ant. Leeuwenhoek. 2017, 110, 375-386. [CrossRef] [PubMed]

8. Galchenko, V.F.; Shishkina, V.N.; Tiurin, V.S.; Trotsenko, Y.A. Isolation of pure methanotrophic cultures and their properties. Mikrobiologiia 1975, 44, 844-850.

9. Gayazov, R.R.; Shishkina, V.N.; Mshensky, Y.N.; Trotsenko, Y.A. Effect of temperature on growth and metabolism of Methylomonas methanica. Doklady of Academy of Science 1985, 284, 746-748. (in Russian).

10. Trotsenko, Y.A.; Shishkina, V.N. Studies on phosphate metabolism in obligate methanotrophs. FEMS Microbiol. Rev. 1990, 87, 267-271. [CrossRef]

11. Weisburg, W.G.; Barns, S.M.; Pelletier, D.A.; Lane, D.J. $16 \mathrm{~S}$ ribosomal DNA amplification for phylogenetic study. J. Bacteriol. 1991, 173, 697-703. [CrossRef] [PubMed]

12. Holmes, A.J.; Costello, A.; Lidstrom, M.E.; Murrell, J.C. Evidence that particulate methane monooxygenase and ammonia monooxygenase may be evolutionarily related. FEMS Microbiol. Lett. 1995, 132, $203-208$. [CrossRef]

13. Costello, A.M.; Lidstrom, M.E. Molecular characterization of functional and phylogenetic genes from natural populations of methanotrophs in lake sediments. Appl. Environ. Microbiol. 1999, 65, 5066-5074. [PubMed] 
14. Sambrook, J.F.; Russell, D.W. Molecular Cloning: A Laboratory Manual, 3rd ed.; Cold Spring Harbor Laboratory Press: New York, NY, USA, 2001.

15. Laemmli, U.K. Cleavage of structural proteins during the assembly of the head of bacteriophage T4. Nature 1970, 227, 680-685. [CrossRef]

16. Slater, G.G. Stable pattern formation and determination of molecular size by pore-limit electrophoresis. Anal. Chem. 1969, 41, 1039-1041. [CrossRef] [PubMed]

17. Leitao, J.M.; Lorenz, B.; Bachinski, N.; Wilhelm, C.; Muller, W.; Schroder, H.C. Osmotic-stress-induced synthesis and degradation of inorganic polyphosphates in the alga Phaeodactylum tricornutum. Mar. Ecol. Prog. Ser. 1995, 121, 279-288. [CrossRef]

18. Thomson, J.D.; Gibson, T.J.; Plewniak, F.; Jeanmougin, F.; Higgins, D.G. The CLUSTAL_X windows interface: Flexible strategies for multiple sequence alignment aided by quality analysis tools. Nucl. Acids Res. 1997, 24, 4876-4882. [CrossRef]

19. Tamura, K.; Dudley, J.; Nei, M.; Kumar, S. MEGA4: Molecular evolutionary genetics analysis (MEGA) software version 4.0. Mol. Boil. Evol. 2007, 24, 1596-1599. [CrossRef] [PubMed]

20. Philips, N.F.B.; Horn, P.J.; Wood, H.G. The polyphosphate and ATP-dependent glucokinase from Propionibacterium shermanii: Both activities are catalyzed be the same protein. Arch. Biochem. Biophys. 1993, 300, 309-319. [CrossRef]

21. Lindner, S.N.; Knebel, S.; Pallerla, S.R.; Schoberth, S.M.; Wendisch, V.F. Cg2091 encodes a polyphosphate/ATP-dependent glucokinase of Corynebacterium glutamicum. Appl. Microbiol. Biotechnol. 2010, 87, 703-713. [CrossRef]

22. Hansen, T.; Reichstein, B.; Schmid, R.; Schonheit, P. The first archaeal ATP-dependent glucokinase, from the hyperthermophilic crenarchaeon Aeropyrum pernix, represents a monomeric, extremely thermophilic ROK glucokinase with broad hexose specificity. J. Bacteriol. 2002, 184, 5955-5965. [CrossRef] [PubMed]

23. Pimentel-Schmitt, E.; Thomae, A.; Amon, J.; Klieber, M.A.; Roth, H.M.; Muller, Y.A.; Jahreis, K.; Burkovski, A.; Titgemeyer, F. A glucose kinase from Mycobacterium smegmatis. J. Mol. Microbiol. Biotechnol. 2007, 12, 75-81. [CrossRef] [PubMed]

24. Liao, H.; Myung, S.; Zhang, Y.H. One-step purification and immobilization of thermophilic polyphosphate glucokinase from Thermobifida fusca YX: Glucose-6-phosphate generation without ATP. Appl. Microbiol. Biotechnol. 2012, 93, 1109-1117. [CrossRef] [PubMed]

25. Mukai, T.; Kawai, S.; Matsukawa, H.; Matuo, Y.; Murata, K. Characterization and molecular cloning of a novel enzyme, inorganic polyphosphate/ATP-glucomannokinase, of Arthrobacter sp. strain KM. Appl. Environ. Microbiol. 2003, 69, 3849-3857. [CrossRef] [PubMed]

26. Tanaka, S.; Lee, S.O.; Hamaoka, K.; Kato, J.; Takiguchi, N.; Nakamura, K.; Ohtake, H.; Kuroda, A. Strictly polyphosphate-dependent glucokinase in a polyphosphate-accumulating bacterium, Microlunatus phosphovorus. J. Bacteriol. 2003, 185, 5654-5656. [CrossRef]

27. Klemke, F.; Beyer, G.; Sawade, L.; Saitov, A.; Korte, T.; Maldener, I.; Lockau, W.; Nurnberg, D.J.; Volkmer, T. All1371 is a polyphosphate-dependent glucokinase in Anabaena sp. PCC 7120. Microbiology 2014, 160, 2807-2819. [CrossRef]

28. Alia, A.; Wathesb, D.C.; Swalic, A.; Burnsa, H.; Burnsa, S. A novel mammalian glucokinase exhibiting exclusive inorganic polyphosphate dependence in the cell nucleus. Biochem. Biophys. 2017, 12, 151-157. [CrossRef]

29. Hsieh, P.C.; Shenoy, B.C.; Jentoft, J.E.; Phillips, N.F. Purification of polyphosphate and ATP glucose phosphotransferase from Mycobacterium tuberculosis H37Ra: Evidence that poly(P) and ATP glucokinase activities are catalyzed by the same enzyme. Protein Expr. Purif. 1993, 4, 76-84. [CrossRef]

30. Lunin, V.V.; Li, Y.; Schrag, J.D.; Iannuzzi, P.; Cygler, M.; Matte, A. Crystal structures of Escherichia coli ATP-dependent glucokinase and its complex with glucose. J. Bacteriol. 2004, 86, 6915-6927. [CrossRef]

31. Kawai, S.; Mukai, T.; Mori, S.; Mikami, B.; Murata, K. Hypothesis: Structures, evolution, and ancestor of glucose kinases in the hexokinase family. J. Biosci. Bioeng. 2005, 99, 320-330. [CrossRef]

32. Shishkina, V.N.; Trotsenko, Y.A. Effect of glucose on growth and metabolism of obligate methanotrophs. Microbiology 1988, 57, 917-923. 
33. Hirayama, H.; Fuse, H.; Abe, M.; Miyazaki, M.; Nakamura, T.; Nunoura, T.; Furushima, Y.; Yamamoto, H.; Takai, K. Methylomarinum vadi gen. nov., sp. nov., a methanotroph isolated from two distinct marine environments. Int. J. Syst. Evol. Microbiol. 2013, 63, 1073-1082. [CrossRef] [PubMed]

34. Flynn, J.D.; Hirayama, H.; Sakai, Y.; Dunfield, P.F.; Klotz, M.G.; Knief, C.; Op den Camp, H.J.M.; Jetten, M.S.M.; Khmelenina, V.N.; Trotsenko, Y.A.; et al. Draft genome sequences of gammaproteobacterial methanotrophs isolated from marine ecosystems. Genome Announc. 2016, 4, e01629-15. [CrossRef] [PubMed]

(C) 2019 by the authors. Licensee MDPI, Basel, Switzerland. This article is an open access article distributed under the terms and conditions of the Creative Commons Attribution (CC BY) license (http:/ / creativecommons.org/licenses/by/4.0/). 